\title{
ALOMORF NASALISASI DAN NASAL PENAMBAH DALAM BAHASA BIDAYUH-SOMU
}

\author{
Eusabinus Bunau \\ Jurusan Pendidikan Bahasa dan Seni FKIP Untan, Pontianak \\ Email: eusabunau@yahoo.com
}

\begin{abstract}
This is a research on linguistics field, that is Nasalization Process of Bidayuh-Somu language. Nasalization is is a process of affixation as one of word formation processes. The Nasalization is one of processes to derive verb, that is transitive verb. Result of the research shows, the Nasalization Process in the Bidayuh-Somu language is applied through affixation of Nasalization morpheme and its variants comprising allomorphs and homorganic nasals to root word. Analysis on structure shows, Nasalization in the Bidayuh-Somu langauge applies by replacing and/or adding root word with the allomorphs and homorganic nasals. Therefore, the Nasalization in the Bidayuh-Somu language functions both as class-maintaining and class-changing. As class-maintaining, the Nasalization is prefixed to root word that is verbal. Meanwhile as class-changing, the Nasalization in this Bidayuh-Somu language is prefixed to root word that is nominal. Besides, it was also found out that the Nasalization is functioned to derive active verb, that is transitive verb.
\end{abstract}

\section{Keywords: Nasalization Process, Morpheme and Nasalization Allomorph, Repalcive and Additive Nasalization.}

\section{PENDAHULUAN}

Penelitian ini adalah penelitian tentang proses nasalisasi, yaitu satu sub-bagian dari proses pembentukan kata melalui pengimbuhan. Dengan demikian, penelitian ini adalah penelitian tentang morfologi melalui proses pengimbuhan, dan dibatasi kepada proses nasalisasi. Proses morfologi, menurut Ramlan (1990:15), terdiri dari sekurang-kurangnya tiga proses, yaitu pengimbuhan, penggandaan dan pemajemukan. Seterusnya, pengimbuhan, termasuk nasalisasi, adalah proses menambahkan morfem terikat atau imbuhan kepada morfem bebas atau kata dasar. Morfem terikat atau imbuhan tersebut terdiri dari morfem awalan, morfem akhiran, morfem sisipan, dan morfem terikat-terbagi (lihat
Harimurti Kridalaksana, 1996:28-29). Lebih lanjut, pengimbuhan menurut Abdullah Hassan (2007:132), adalah proses pembentukan kata berimbuhan dengan menambahkan imbuhan kepada morfem bebas atau kata dasar. Dengan demikian, berdasarkan kedudukannya, yaitu sebelum morfem bebas atau kata dasar, nasalisasi merupakan morfem imbuhan, yaitu awalan. Namun demikian, nasalisasi tidak sepenuhnya dapat dianggap awalan karena bentuknya tidak dalam bentuk sukuan (lihat Rohani Mohd Yusof, 1999:105).

Denham dan Lobeck (2010:147) mengemukakan bahwa imbuhan adalah morfem yang diimbuhkan kepada morfem lain, yaitu morfem bebas atau kata dasar melalui suatu proses yang disebut sebagai 
pengimbuhan. Oleh karena itu, imbuhan adalah morfem terikat, yaitu awalan, akhiran, sisipan dan morfem terikat-terbagi. Dari segi kedudukan, morfem awalan adalah sebelum morfem bebas atau kata dasar, morfem akhiran adalah sesudah morfem bebas, morfem sisipan adalah di antara fonem konsonan pertama dan fonem vokal kedua dari morfem bebas, dan morfem terikatterbagi adalah sebelum dan sesudah morfem bebas atau kata dasar (lihat Harimurti Kridalaksana, 1996:28-29). Seterusnya, morfem terikat seperti dinyatakan oleh Kieffer dan Lesaux (2007) terbagi kepada morfem infleksi dan derivasi. Namun begitu, untuk penelitian ini morfem terikat tersebut adalah morfem derivasi, yaitu morfem nasalisasi atau morfem awalan. Morfem derivasi adalah morfem imbuhan yang berfungsi menetapkan atau mengubah golongan kata atau bermakna menetapkan atau mengubah kelas kata (lihat Kieffer dan Lesaux, 2007:137).

Penelitian ini merupakan penelitian mengenai pembentukan kata kompleks tak setara atau kata berlapis dari Bahasa BidayuhSomu, yaitu kata kerja aktif yang terbentuk dengan morfem nasalisasi dan alomorfalomorfnya. Kata kompleks berdasarkan struktur, terdiri dari sekurang-kurangnya satu morfem bebas + satu morfem terikat, satu morfem bebas + satu morfem bebas, atau satu morfem terikat + satu morfem bebas, atau satu morfem terikat + satu morfem bebas + satu morfem terikat (lihat Asmah Haji Omar, 2009:21). Seterusnya untuk penelitian ini, pembentukan kata kerja aktif dari Bahasa Bidayuh-Somu melibatkan morfem nasalisasi yang terbentuk dengan struktur Nasalisasi + Morfem Bebas.

Bahasa Bidayuh-Somu dituturkan oleh masyarakat Bidayuh-Somu yang tinggal di 44 kampung di dua Kecamatan, yaitu Kembayan dan Noyan di Kabupaten Sanggau, Provinsi Kalimantan Barat, Indonesia (Sujarni Alloy, dkk., 2008). Kedua kecamatan tersebut berada sekitar 40 kilometer dari perbatasan Kalimantan-Indonesia dan Sarawak-Malaysia (silahkan lihat peta di bawah). Bahasa Bidayuh-Somu tersebut dituturkan oleh kirakira sebanyak 40,166 orang (sumber: Kantor Kependudukan dan Catatan Sipil Kabupaten Sanggau, 2014). Seterusnya, secara umum masyarakat Bidayuh-Somu bekerja sebagai petani dan pekebun serta terdapat sedikit yang bekerja sebagai pegawai negeri. Keberadaan masyarakat Bidayuh-Somu penutur Bahasa Bidayuh-Somu dapat dilihat pada peta di bawah ini:

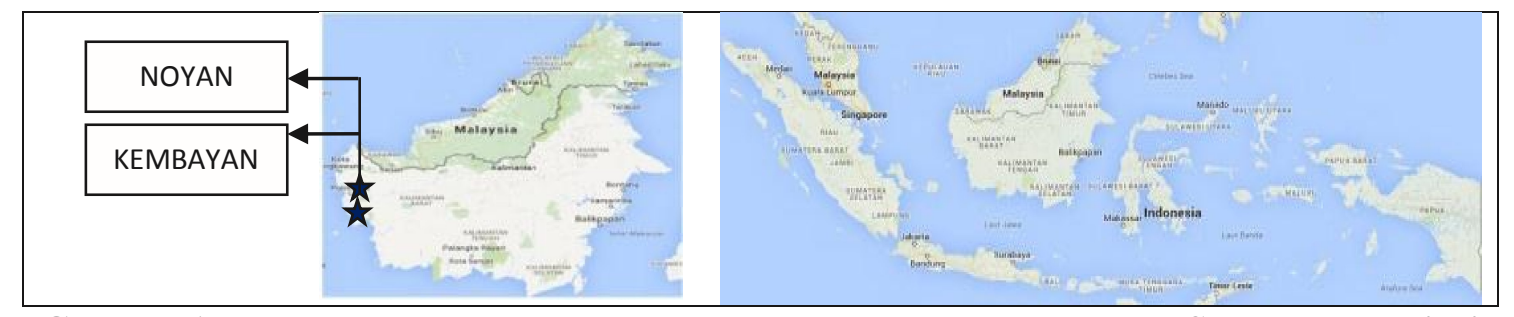

Gambar 1. Peta Letak Kecamatan Kembayan dan Noyan, Kabupaten Sanggau, Provinsi Kalimantan Barat, Indonesia

(Sumber: Kantor Bupati Sanggau, 2014)

Skop penelitian ini adalah pengimbuhan yang melibatkan proses nasalisasi pada bagian awal morfem bebas atau kata dasar. Kajian ini bertujuan untuk mengidentifikasi morfem nasalisasi dan alomorf-alomorf atau variasi- variasinya, dan mendeskripsikan proses nasalisasi untuk membentuk kata kerja aktif dari pada Bahasa Bidayuh-Somu. Rumusan masalah dan tujuan penelitian ini adalah alomorf dan nasal yang termasuk morfem 
nasalisasi dalam Bahasa Bidayuh-Somu, alomorf pengganti dan penambah serta nasal penambah, nasalisasi sebagai penetap dan pengubah golongan kata.

Hasil penelitian ini relevan untuk menambah khasanah penelitian di bidang morfologi, khususnya Nasalisasi serta relevan sebagai sumber atau rujukan bagi penelitianpenelitian serupa untuk bahasa-bahasa lain di Nusantara yang belum diteliti. Akhirnya, penelitian ini relevan sebagai satu upaya untuk mendokumentasikan atau merekam dan mempublikasikan supaya menjadi pengetahuan linguistik, khususnya di bidang Nasalisasi bagi masyarakat awam, masyarakat akademik pembelajar bahasa dan para peneliti bahasa yang lain.

Teori yang dirujuk untuk penelitian ini adalah teori struktural, yaitu teori yang melihat bahwa suatu kata mempunyai struktur atau rangka tertentu (lihat Bloomfield, 1994). Struktur atau rangka kata tersebut boleh terdiri dari pada gabungan atas morfem bebas dan morfem terikat, atau merupakan gabungan dari imbuhan dan kata dasar atau kata akar. Dengan demikian, berdasarkan struktur atau rngka, kata terdiri dari kata tunggal, yaitu morfem bebas dan kata kompleks yang terbagi atas kata berlapis dan kata majmuk (lihat de Saussure, 1986, dan Crystal, 1980).

Nasalisasi dalam pembentukan kata mengacu kepada proses menambah atau menggantikan fonem pertama kata dasar dengan fonem yang homorgan atau homorganik (lihat Asmah Haji Omar, 2013:48 dan Rohani Mohd Yusof, 1999:105). Dalam hal ini nasalisasi boleh berfungsi sebagai pengganti dan penambah. Nasalisasi yang berfungsi sebagai pengganti adalah proses yang menggantikan fonem pertama kata dasar dengan bunyi nasal, sedangkan nasalisasi yang berfungsi sebagai penambah adalah proses meletakkan bunyi nasal sebelum kata dasar (lihat Rohani Mohd Yusof, 1999:124 dan 136). Oleh karena itu, nasalisasi berarti suatu proses mengganti dan/atau menambah fonem pertama kata dasar dengan fonem nasal atau merupakan proses peleburan fonem melalui penyengauan pada fonem pertama kata akar atau kata dasar.Berdasarkan kedudukannya dalam kata, nasalisasi merupakan imbuhan awalan. Walaupun demikian nasalisasi tidak boleh dianggap sebagai awalan sepenuhnya karena kehadirannya tidak dalam bentuk sukuan atau suku kata (lihat Rohani Mohd Yusof, 1999:105).

Seterusnya, berdasarkan kata bentukan yang terbentuk dari proses nasalisasi, yaitu kata kerja aktif, maka nasalisasi merupakan morfem atau awalan verbal. Asmah Haji Omar (2013:47) menyatakan bahwa nasalisasi merupakan morfem verbal yang berfungsi baik sebagai penetap maupun pengubah golongan kata. Oleh karena itu, nasalisasi sebagai penetap golongan kata ditambahkan kepada kata dasar golongan kerja dan sifat, sedangkan nasalisasi sebagai pengubah golongan kata, ditambahkan kepada kata dasar golongan benda. Dengan fungsi penetap, nasalisasi menandakan bahwa kata kerja adalah kata kerja transitif. Seterusnya, nasalisasi sebagai pengubah golongan kata menghasilkan kata verbal dari kata nominal (lihat Asmah Haji Omar, 2013:47-48).

Nasalisasi merupakan morfem verbal dan berfungsi sebagai penetap dan pengubah golongan kata. Sebagai penetap, nasalisasi diimbuhkan kepada kata kerja dan kata sifat serta menandakan bahwa kata kerja adalah kata kerja aktif. Sebagai pengubah, nasalisasi diimbuhkan kepada kata benda atau menghasilkan kata verbal dari pada kata nominal (lihat Asmah Haji Omar, 2013:4748). Dengan demikian dapat dikatakan, nasalisasi berarti suatu proses mengganti atau menambah fonem awal dari pada morfem bebas atau kata dasar menggunakan fonem nasal.

Kaidah atau metode yang digunakan dalam penelitian ini kaidah penelitian huluan (upstream research) yang dilakukan secara deskriptif (lihat Asmah Haji Omar, 2008:6) dengan teknik pengumpulan data, yaitu merekam (recording). Data yang dipilih dan dibahas dalam penelitian ini adalah data Bahasa Bidayuh-Somu yang mengandung 
morfem nasalisasi dan variasi-variasinya (lihat Sudaryanto, 1990). Sumber data penelitian adalah informan penutur asli Bahasa BidayuhSomu, baik laki-laki maupun perempuan, dan berumur 35-50 tahun. Pendekatan yang digunakan dalam penelitian ini adalah kualitatif (Asmah Haji Omar, 2008). Memperhatikan bahwa morfem berfungsi sebagai penetap dan pengubah golongan kata, maka pendekatan Sistemik (Berry, 1975) juga digunakan dalam kajian ini. Teknik pemilahan data adalah teknik elisitasi atau penyortiran data berdasarkan kelompok atau golongan data, misalnya kelompok alomorf pengganti dan penambah. Analisis data dilakukan dengan teknik deskriptif. Analisis deskriptif bagi penelitian bahasa adalah analisis yang dilakukan untuk mendeskripsikan suatu bahasa (lihat Samsuri, 1980:70).

\section{Hasil dan Pembahasan}

Hasil analisis data menunjukkan bahwa nasalisasi juga terdapat dalam Bahasa Bidayuh-Somu dan dapat berfungsi sebagai penetap dan pengubah golongan kata, serta menghasilkan kata kerja aktif. Sebagai penetap golongan kata, nasalisasi hadir bersama kata akar dan golongan kata kerja, dan sebagai pengubah golongan, nasalisasi hadir dengan kata akar golongan benda dan sifat. Fungsi ini bergantung kepada kata akar yang hadir bersama unsur nasal tersebut. Di samping itu, morfem nasalisasi ini mempunyai daftar alomorfnya tersendiri. Karena itu berdasarkan data didapati bahwa morfem nasalisasi dalam Bahasa BidayuhSomu seperti juga dalam bahasa Iban (lihat Asmah Haji Omar, 2013:45), dapat dibagikan kepada tiga alomorf, yaitu:

1. Alomorf $/ \sim$ (D/

2. Alomorf $/ \mathrm{Ne}-/$

3. Alomorf $/ \mathrm{Ni}-/$

Setiap alomorf di atas mempunyai peraturannya masing-masing. Alomorf / (D/ adalah alomorf yang diwakili oleh bunyibunyi nasal $/ \mathrm{m} /, / \mathrm{n} /, / \otimes /$ dan $/ ₫ /$. Analisis data menunjukkan bahwa nasal $/ \mathrm{m} /, \mathrm{n} /$, dan $/ \mathrm{N} /$ boleh merupakan pengganti dan penambah, sedangkan nasal $/ \square /$ hanya merupakan nasal pengganti. Selanjutnya, berdasarkan contoh-contoh proses nasalisasi dari Bahasa Bidayuh-Somu juga menunjukkan bahwa alomorf /Ne-/ dan alomorf $/ \mathrm{Ni}-/$ merupakan alomorf penambah. Dari analisis data, yaitu kata-kata dalam Bahasa BidayuhSomu diketahui bahwa alomorf / (D/ yang diwakili oleh bunyi-bunyi nasal $/ \mathrm{m} /, / \mathrm{n} /$, $/ \otimes /$ dan $/ ₫ /$ merupakan bagian dari morfem-morfem terikat. Morfem-morfem dengan unsur nasalisasi tersebut terdiri dari $\{\mathrm{kuN}-\}, \quad\{\mathrm{puN}-\},\{\mathrm{buN}-\}$, dan $\{$ niN\}. Penambahan unsur-unsur vokal /i/ dan /e/ untuk alomorf $/ \mathrm{N}-/$ menjadi alomorf $/ \mathrm{Ni}-/$ dan alomorf $/ \mathrm{Ne}$-/ adalah berdasarkan lingkungan atau bunyi-bunyi fonem pertama kata akar dari Bahasa Bidayuh-Somu. Seterusnya, nasalisasi dalam Bahasa Bidayuh-Somu mempunyai makna-makna tertentu tergantung pada ciri-ciri kata akar. Berdasarkan analisis data, didapati nasalisasi dari Bahasa Bidayuh-Somu mempunyai kemiripan dengan nasalisasi dalam Bahasa Iban yang dituturkan di Sarawak (lihat Asmah Haji Omar, 2013:45).

\section{Nasalisasi sebagai Pengganti}

Nasalisasi sebagai pengganti yang dilambangkan dengan alomorf / () / mengacu kepada proses nasalisasi yang boleh merupakan pengganti. Alomorf / (D) / tersebut mewakili bunyi-bunyi $/ \mathrm{m} /, / \mathrm{n} /, / \mathbf{8} /$, dan $/ ₫ /$ yang merupakan nasal pengganti kepada fonem pertama kata akar yang terdiri dari bunyi-bunyi konsonan yang homorgan. Pada dasarnya konsonan $\mathrm{m} /, \mathrm{n} /, \mathrm{g} / \mathrm{\&} /$, dan $/ \searrow /$ menggantikan fonem pertama kata akar yang terdiri dari konsonan bersuara dan tak bersuara seperti fonem konsonan plosif, afrikat dan frikatif. Dalam proses mengganti 
ini akan menyebabkan fonem pertama kata akar dihilangkan dan digantikan dengan fonem nasal. Peraturan ini tergambarkan dalam Tabel 1 berikut:

Tabel 1: Fonem Pertama Kata Akar dan Alomorf/Nasal Pengganti dalam Bahasa Bidayuh-Somu

\begin{tabular}{|c|c|c|}
\hline Konsonan & Fonem Pertama Kata Akar & Alomorf/Nasal Pengganti \\
\hline \multirow{3}{*}{ Plosif } & $/ \mathrm{p} /, / \mathrm{b} /$ & $/ \mathrm{m}-/$ \\
\hline & $/ \mathrm{t} /, / \mathrm{d} /$ & $/ \mathrm{n}-/$ \\
\hline & $/ \mathrm{k} /, \mathrm{g} /$ & / $2-1$ \\
\hline Afrikat & $/ \mathrm{c} /, / \mathrm{j} /$ & $/ \unlhd-/$ \\
\hline \multirow{2}{*}{ Frikatif } & $/ \mathrm{s} /$ & $/ \unlhd-/$ \\
\hline & $/ \mathrm{h} /$ & / $x-1$ \\
\hline
\end{tabular}

Tabel 1 di atas menunjukkan bahwa nasal $/ \mathrm{m} /$ dalam Bahasa Bidayuh-Somu merupakan pengganti kepada fonem plosif $/ \mathrm{p} /$ dan $/ \mathrm{b} /$. Seterusmya nasal $/ \mathrm{n} /$ pula adalah pengganti kepada fonem kata akar yang diawali oleh fonem plosif $/ \mathrm{t} / \mathrm{dan} / \mathrm{d} /$. Selanjutnya, nasal / / pula merupakan pengganti kepada fonem pertama kata akar yang didahului oleh fonem plosif $/ \mathrm{k} / \mathrm{dan} / \mathrm{g} /$ serta fonem frikatif $/ \mathrm{h} /$, sedangkan nasal $/ ₫ /$ adalah pengganti kepada fonem pertama kata akar yang dimulai oleh fonem afrikat /c/ dan $/ j /$ serta fonem frikatif $/ \mathrm{s} /$.

\subsection{Alomorf $/ \mathrm{m}-/$}

Alomorf $/ \mathrm{m}-/$ adalah sebagian dari proses nasalisasi. Berdasarkan kajian diketahui, alomorf $/ \mathrm{m}-/$ dalam Bahasa Bidayuh-Somu merupakan penetap (silahkan lihat contoh nomor 1-5) dan pengubah golongan kata (silahkan lihat contoh nomor 67). Alomorf ini kemudian boleh ditambahkan kepada kata akar dari golongan kata kerja dan kata benda. Alomorf /m-/ ini wujud apabila kata akar dimulai dengan fonem plosif $/ \mathrm{p} /$ dan /b/. Dalam hal ini, alomorf $/ \mathrm{m}-/$ bersifat pengganti. Keadaan yang demikian itu menyebabkan fonem plosif / $\mathrm{p} /$ dan /b/ pada awal kata akar akan hilang dan digantikan dengan fonem homorganik /m/. Berdasarkan fungsi, alomorf $/ \mathrm{m}$-/ dalam Bahasa Bidayuh-
Somu boleh berfungsi sebagai penetap dan pengubah golongan kata. Berikut ini adalah contoh-contohnya:

a. Alomorf $/ \mathrm{m}-/$ sebagai penetap golongan kata:

1. /poNko?/ = tabrak /moNko?/ = menabrak

2. $/$ piris $/=$ pilas /miris/ = memilas

3. $/$ pacual/ = lepas, cabut $/ \mathrm{macual} /$ = melepas, mencabut

4. /botat/ = buang $/ \mathrm{motat} /=$ membuang

5. $/$ borut/ = gulung (tikar) /morut/ = menggulung (tikar)

b. Alomorf $/ \mathrm{m}-/$ sebagai pengubah golongan kata:

6. $/$ botuh $/=$ batu $/$ motuh $/=$ membatu

7. $/$ pokuh/ = pakis /mokuh/ = mencari pakis

8. $/$ bota/ = batang $/ \mathrm{mota} / \quad=$ sakit keram

Dari contoh-contoh didapati, alomorf /m-/ lebih kerap berlaku kepada kata akar golongan kata kerja dibandingkan dengan golongan kata benda dan kata sifat. Oleh karena itu dapat dikatakan bahwa alomorf $/ \mathrm{m} /$ lebih berfungsi sebagai penetap dibandingkan fungsi sebagai pengubah golongan kata. Dari contoh yang diperoleh memperlihatkan bahwa 
proses nasalisasi dengan alomorf $/ \mathrm{m}$-/ ini lebih kerap berlaku kepada kata akar dari Bahasa Bidayuh-Somu yang diawali oleh fonem konsonan tak bersuara $/ \mathrm{p} /$. Seterusnya berdasarkan keberadaan obyek dalam kalimat, pengimbuhan alomorf /m-/ kepada kata akar dalam Bahasa Bidayuh-Somu menghasilkan kata kerja transitif. Di samping itu, pengimbuhan alomorf $/ \mathrm{m}-/$ menunjukkan makna 'proses menjadi'. Kata kerja transitif dan makna tersebut adalah seperti pada contoh kalimat dari cerita rakyat dalam Bahasa Bidayuh-Somu berikut:

/usa? jeh lodi botuh lobuar ${ }^{1}$, moru jeh motuh kosuh ay ge?Neh/

(karena sudah menjadi kiamat, lantas sudah membatu anjing itu juga nya)

/karna sudah menjadi batu, maka anjing tersebut juga ikut membatu/

\subsection{Alomorf $/ \mathbf{n}-/$}

Keberadaan alomorf /n-/ dalam Bahasa Bidayuh-Somu didapati hadir pada kata akar yang terdiri dari golongan kata kerja dan kata benda. Alomorf ini boleh hadir apabila kata akar didahului oleh fonem plosif /t/ dan $/ \mathrm{d} /$. Oleh karena itu, kehadiran alomorf /n-/ dalam Bahasa Bidayuh-Somu bersifat sebagai pengganti dan menyebabkan fonem plosif /t/ dan /d/ pada kata akar hilang. Perhatikan contoh berikut:

a. Alomorf $/ \mathrm{n}-/$ sebagai penetap golongan kata:
1. $/$ tonta/ $=$ tantang /nonta/ = menantang
2. $/$ tujo/ $=$ tusuk /nujo/ = menusuk
3. $/ \mathrm{doruh} /=$ marah /noruh/ = memarahi

b. Alomorf $/ \mathrm{n}-/$ sebagai pengubah golongan kata:
4. $/$ dodos/ = pisau panen (sawit) /nodos/ = memanen (sawit)

\footnotetext{
${ }^{1}$ Hari kiamat yang disebabkan oleh petir dan angin puting beliung
}

$$
\begin{aligned}
\text { 5. /doput/ } & =\text { hasil } \\
\text { /noput/ } & =\text { menghasilkan } \\
\text { 6. } / \text { totow/ } & =\text { tawa } \\
\text { /notow/ } & =\text { tertawa } \\
\text { 7. } / \text { tatey/ } & =\text { bukit } \\
\text { /natey/ } & =\text { berbukit }
\end{aligned}
$$

Berdasarkan data menununjukkan bahwa alomorf /n-/ dalam Bahasa BidayuhSomu berfungsi sebagai penetap golongan kata (lihat contoh nomor 1-3) dan pengubah golongan kata (lihat contoh nomor 4-7). Seterusnya, pengimbuhan alomorf ini kepada kata akar menghasilkan kata kerja transitif tergantung pada kehadiran obyek dalam kalimat dari Bahasa Bidayuh-Somu. Berdasarkan analisis didapati, penggantian fonem yang homorganik dengan nasal $/ \mathrm{n} /$ menerbitkan kata kerja transitif serta menunjukkan ciri atau makna 'melakukan sesuatu'. Perhatikan contoh kalimat berikut ini:

$/ y \leftrightarrow a$ ? dege? noruh ona?mu?, matE? $\lambda \alpha \chi v \alpha / \alpha \mathrm{N \varepsilon \eta /}$

(jangan selalu memarahi anakmu, nanti merajuk dia nya) /jangan selalu memarahi anakmu, nanti merajuk pula dia/

\section{Alomorf / $₫-/$}

Berdasarkan analisis didapati, alomorf / 2 -/ dalam Bahasa Bidayuh-Somu dapat diimbuhkan kepada kata akar yang terdiri dari golongan kata kerja dan kata benda. Berdasarkan struktur, alomorf tersebut hadir di bagian awal kata akar yang didahului oleh fonem plosif $/ \mathrm{k} /, \mathrm{g} /$ dan frikatif $/ \mathrm{h} /$. Proses penggantian fonem awal kata akar dengan alomorf $/ \mathrm{N}-/$ ini menyebabkan hilang atau tergantinya fonem awal kata akar dengan ciriciri yang homorgan. Contoh-contohnya, yaitu:
1. $/$ kaluah $/=$ sahut
/ aaluah/ = menyahut
2. $/ \mathrm{kajoh} /=$ tebas, potong
/ ajoh/= menebas, memotong
3. $/$ kolua/ $=$ kepung
/ olua/ = mengepung 
4. $/$ gorat/ = kibas

/※orat/= mengibas

5. $/$ golua/ = gulung (tali)

/ olua/ = menggulung (tali)

6. $/$ gocoh/ = pukul, tinju

/ ocoh/ = memukul, meninju

7. $/$ kosuh $/=$ anjing

/ osuh/ = berburu (dengan anjing)

8. /honda/ = sepeda motor

/ $₫$ onda/ = mengendarai sepeda motor

Berdasarkan contoh-contoh di atas didapati, nasalisasi pengganti yang terjadi dengan alomorf $/ \mathrm{N}-/$ dalam Bahasa BidayuhSomu dapat berfungsi sebagai penetap golongan kata dan pengubah golongan kata. Dengan kata lain, sebagai penetap golongan kata, alomorf $/ \mathrm{N}-/$ hadir bersama kata akar golongan verbal. Sedangkan sebagai pengubah golongan kata, alomorf ini hadir bersama kata akar golongan nominal. Berdasarkan jumlah contoh, didapati alomorf /N-/ lebih kerap berfungsi sebagai penetap golongan kata (lihat contoh nomor 1-6) dibandingkan sebagai pengubah golongan kata (lihat contoh nomor 7-8). Berdasarkan fungsi nasalisasi, yaitu menerbitkan kata kerja aktif, alomorf $/ \mathrm{N}-/$ ini menerbitkan kata kerja tak transitif dan menandakan makna 'melakukan sesuatu'. Perhatikan kalimat yang bersumber dari cerita rakyat Bahasa BidayuhSomu berikut:

losik sonta Nat $\leftrightarrow p$, oji narut datNeh, Nosuh no? uta? maNkey ${ }^{2} /$

(habis musim panen, pergi berburu mereka, berburu di hulu maNkey)

/habis musim panen, mereka pergi berburu ke hulu maNkey/

\subsection{Alomorf $/ \varsigma-/$}

Analisis terhadap kata dalam Bahasa Bidayuh-Somu menunjukkan, alomorf / $/ ₫-/$ dapat menggantikan fonem kata akar yang terdiri dari golongan verbal dan nominal. Karena itu pula, alomorf tersebut merupakan penetap (silahkan lihat contoh nomor 1-8) dan pengubah golongan kata (silahkan lihat contoh nomor 9-12). Analisis terhadap alomorf $/ \square-/$ memperlihatkan, alomorf ini dapat ditambahkan kepada kata akar yang diawali dengan fonem afrikat $/ \mathrm{c} / \mathrm{dan} / \mathrm{j} / \mathrm{dan}$ frikatif $/ \mathrm{s} /$. Penambahan alomorf tersebut kepada kata akar dari Bahasa Bidayuh-Somu mengakibatkan fonem afrikat $/ \mathrm{c} /$ dan $/ \mathrm{j} / \mathrm{dan}$ frikatif /s/ dalam kata akar hilang atau digantikan oleh alomorf //./. Contohcontohnya adalah sebagai berikut:

a. Alomorf //-/ sebagai penetap golongan kata:
1. $/$ cocap $/=$ rasa / צocap/ = merasa
2. $/$ soman/ = sakit / \oman/= menderita sakit
3. $/$ ciNap/ = habis (napas) / siNap/ = habis napas
4. $/$ jigat $/=$ diri / sigat/ = mendirikan
5. /jalat/ = jalan / צalat $/$ = menjalankan
6. /jodi/ = jadi / צodi/ = menjadi
7. $/$ sobu/ = rumput $/$ sobu $/$ = merumput
8. /sara?/ = cerai / \ara?/ = menceraikan

b. Alomorf /)-/ sebagai pengubah golongan kata:
9. $/$ sarih/ = lantai
/ צarih/ = memasang lantai
10. $/$ saley $/$ = salai / valey/ = menyalai
11. $/$ samal $/$ = sambal / samal/ = menyambal
12. $/$ cokas $/$ = pakis merah / צokas $/$ = mencari pakis merah 
Data Bahasa Bidayuh-Somu di atas memperlihatkan, poses nasalisasi dengan alomorf //)/ lebih sering terjadi dengan kata akar dari golongan kata kerja. Oleh karena itu, nasalisasi dengan alomorf //-/ lebih kerap berfungsi sebagai penetap golongan dibandingkan sebagai pengubah golongan kata. Berdasarkan fonem awal kata akar menandakan, proses nasalisasi alomorf //)/ lebih sering terjadi dengan fonem afrikat /c/ dan /j/ dibandingkan fonem frikatif /s/. Berdasarkan fungsi pula, alomorf //-/ ini menerbitkan kata kerja transitif. Seterusnya, analisis menunjukkan bahwa alomorf tersebut memiliki makna 'melakukan sesuatu'. Lihat kalimat berikut:

InEsEk balo puraNko no torut la sigat romin/

(gesek banyak bahan/ramuan di hutan untuk mendirikan rumah)

/geseklah banyak bahan/ramuan di hutan untuk mendirikan rumah/

\section{Nasalisasi sebagai Penambah}

Dalam proses nasalisasi terdapat suatu fonem nasal yang berfungsi sebagai pengganti dan penambah kepada fonem awal sesuatu kata akar (silahkan merujuk Asmah Haji Omar, 1981:48). Oleh karena itu, selain sebagai pengganti, nasalisasi dalam BBS boleh berfungsi sebagai penambah. Secara umum, nasalisasi akan berfungsi sebagai penambah apabila berlaku pada alomorf $/ \mathrm{Ne}-/$ dan /Ni-/. Alomorf /Ne-/ merupakan penambah fonem awal kata akar dwisuku yang dimulakan oleh konsonan liquida. Sedangkan alomorf / $\mathrm{Ni} /$ / adalah penambah kepada fonem awal kata akar ekasuku yang didahului oleh konsonan afrikat /c/ dan konsonan liquida. Bagaimanapun data memperlihatkan, dalam Bahasa BidayuhSomu terdapat juga fonem nasal dengan ciri- ciri penambah pada bagian awal kata akar. Fonem nasal berkenaan terdiri dari /m-/, /n-/ dan $/ \mathrm{N}-/$. Berdasarkan contoh-contoh yang diperoleh, nasal /m-/, /n-/ dan /N-/ adalah penambah kepada fonem pertama kata akar yang diawali fonem konsonan homorgan dan vokal.

\section{Nasal penambah /m-/}

Berdasarkan proses nasalisasi dengan nasal penambah dalam Bahasa Bidayuh-Somu didapati, nasal /m-/ memasuki kata akar yang terdiri dari golongan verbal dan nominal. Dengan demikian, nasal tersebut dapat berfungsi sebagai penetap dan pengubah golongan kata. Penelitian yang dilakukan terhadap Bahasa Bidayuh-Somu memperlihatkan bahwa nasal /m-/ bisa hadir sebelum kata akar yang didahului oleh fonem plosif /p/ dan /b/ dan /1/. Seterusnya, penambahan nasal ini bisa terhadi pada kata akar yang pada strukturnya terdapat sistem vokal harmoni. Contoh:

a. Nasal penambah $/ \mathrm{m}-/$ sebagai penetap golongan kata:

1. $/$ polak/ = kasar (kata) /mpolak/ = berkata kasar

2. $/$ pola/ = makan (hanya nasi saja) /mpola/ = makan nasi tak berlauk

3. $/$ laher/ = lahir /mlaher/ = melahirkan

4. $/$ lasah/ = pukul (dengan rotan) /mlasah/ = memukul (dengan rotan)

b. Nasal penambah $/ \mathrm{m}-/$ sebagai pengubah golongan kata:

5. /poriat/ = luka /mpojiat/ = menutup luka

6. $/$ pidal $/$ = padat /mpidal $/$ = menjadi padat

7. $/$ paNey $/=$ menara $/ \mathrm{mpaNey} /=$ bermenara

8. /bunsik/ = arang /mbunsik/= mencoret muka (dengan abu/arang) 


\section{9. $/$ bidat $/=$ bidan \\ /mbidat $/$ = membidani}

Berdasarkan contoh di atas memperlihatkan, nasal $/ \mathrm{m}-/$ dalam Bahasa Bidayuh-Somu merupakan penetap golongan kata (lihat contoh 1-4) dan pengubah golongan kata (lihat contoh 5-9). Seterusnya, dari analisis menunjukkan bahwa pengimbuhan nasal penambah $/ \mathrm{m}-/$ kepada kata akar dalam Bahasa Bidayuh-Somu menghasilkan kata kerja transitif yang menandakan makna 'melakukan sesuatu'. Contohnya adalah seperti dalam kalaimat yang bersumber dari Bahasa Bidayuh-Somu berikut ini:

/man mpola modas, lap laok/

(makan makan tak berlauk, tak ada lauk)

/makannya makan nasi saja, tak berlauk/

\section{Nasal penambah /n-/}

Data Bahasa Bidayuh-Somu memperlihatkan bahwa nasal penambah /n-/ dalam bahasa ini dapat ditambahkan kepada kata akar dari golongan nominal dan verbal. Dengan demikian, nasal berkenaan bisa berfungsi sebagai penetap dan pengubah golongan kata. Analisis yang dilakukan terhadap data Bahasa Bidayuh-Somu menunjukkan bahwa nasal /n-/ ini merupakan penambah kepada kata akar yang dimulai oleh fonem plosif /t/ dan /d/, fonem afrikat /c/ dan $/ \mathrm{j} /$, dan frikatif $/ \mathrm{s} /$. Contoh proses pengimbuhan nasal penambah $/ \mathrm{n}-/$ kepada kata akar Bahasa Bidayuh-Somu, yaitu:

a. Nasal penambah $/ \mathrm{n}-/$ sebagai penetap golongan kata:

1. /tusa?/ = timbul /ntusa?/ = menimbulkan

2. /tulah/ = kutuk /ntulah/ = mengutuk

3. /sarat/ = kejar /nsarat/ = terkejar
4. $/$ caro/ = bahas
/ncaro/ = membahas
5. $/$ jilo/ = kacau
/njilo/ = menngacau

b. Nasal penambah /n-/ sebagai pengubah golongan kata:
6. $/$ cilak/ = celak (mata)
/ncilak/ = mencelakkan mata
7. /tudo?/ = tengah
/ntudo?/ = berdiri (di tengah)
8. $/$ tadu/ = ayam jantan
/ntadu/ = berkokok
9. /jukat/ = pantangan
/njukat/ = berpantang
10./sido?/ = manis
/nsido?/ = merasa manis

Analisis yang dilakukan terhadap contoh-contoh di atas menunjukkan, nasal penambah /n-/ merupakan penetap (lihat contoh 1-5) dan pengubah golongan kata (lihat contoh 6-10). Di samping itu, contohcontoh pula memperlihatkan bahwa pengimbuhan nasal /n-/ kepada kata akar yang didahului oleh konsonan homorganik / $t /$ dan /d/ dapat terjadi apabila di dalam struktur kata akar tersebut terdapat sistem vokal harmoni. Selain itu, didapati bahwa nasalisasi dengan nasal penambah /n-/ dalam Bahasa BidayuhSomu berfungsi menerbitkan kata kerja transitif dan menunjukkan makna 'mampu'. Perhatikan contoh kalimat yang bersumber dari Bahasa Bidayuh-Somu berikut:

lomat di? sinih, moru nsarat datNeh kan $\leftrightarrow h$ omE?

(walaupun yang belakangan, akhirnya terkejar juga mereka oleh kami/

/walaupun (kami) belakangan tetapi terkejar juga mereka oleh kami /

\section{Nasal penambah / $\mathrm{N}-$ /}

Berdasarkan analisis yang dilakukan terhadap nasalisasi dengan penambah didapati, nasal /N-/ dalam Bahasa Bidayuh- 
Somu dapat diimbuhkan kepada kata akar yang terdiri dari golongan verbal dan nominal. Oleh karena itu, nasal / $\mathrm{N}$-/ ini boleh berfungsi sebagai penetap dan pengubah golongan kata. Seterusnya, contoh-contoh pula memperlihatkan bahwa nasal /N-/ dalam bahasa ini boleh ditambahkan kepada kata akar yang didahului oleh fonem plosif $/ \mathrm{k} /, / \mathrm{g} /$, dan fonem vokal. Contoh:

a. Nasal penambah $/ \mathrm{N}-/$ sebagai penetap golongan:

1. /goyuat/ = berjalan (lambat) / : goyuat/ = berjalan (lambat)

2. $/$ kuri?/ = pergi (pulang hari) /×kuri?/ = pergi (pulang hari)

3. $/$ kota?/ = pergi (cepat) / kota?/ = mempercepat

b. Nasal penambah / $\mathrm{N}-/$ sebagai pengubah golongan:

4. /abuh/ = abu dapur / $\gg a b u h /$ = menaburkan (abu dapur)

5. /obor/ = bor / obor/ = mengebor

6. /untal/ = daging / \&untal/ = meratah daging

7. $/$ imey/ = roh / imey/ = menjadi roh

Berdasarkan contoh-contoh diatas, didapati nasal /N-/ merupakan penetap golongan kata (lihat contoh 1-3) dan pengubah golongan kata (lihat contoh 4-7). Penelitian yang dilakukan terhadap contohcontoh tersebut menunjukkan bahwa nasalisasi dengan penambah nasal / N-/ dapat diimbuhkan kepada kata akar yang pada strukturnya terdapat sistem vokal harmoni dan didauhului oleh konsonan homorganik /t/ dan /d/. Seterusnya, proses nasalisasi sebagai penambah dengan nasal $/ \mathrm{N}-/$ dalam Bahasa Bidayuh-Somu menghasilkan kata kerja transitif dengan ciri 'melakukan sesuatu', yaitu: /bunoniah dEgE? Nuntal siap yoh, matE?

lap la? lo man/

(mengapa melulu meratah daging ayam itu, nanti tidak ada lagi lauk untuk orang makan/

/mengapa (kamu) terus meratah daging ayam itu, nanti orang makan tidak berlauk/

\section{Alomorf penambah /Ne-/}

Dari contoh-contoh nasalisasi dengan penambah menunjukkan, alomorf /Ne-/ dalam Bahasa Bidayuh-Somu terdapat pada kata akar yang terdiri dari golongan verbal dan nominal. Dengan demikian, alomorf $/ \mathrm{Ne}-/$ dalam ini bisa berfungsi sebagai penetap dan pengubah golongan kata. Sebagai penetap golongan kata, alomorf tersebut hadir bersama kata akar dari golongan verbal. Sedangkan sebagai pengubah golongan kata, alomorf /Ne-/ ini hadir bersama kata akar dari golongan nominal. Dari kajian yang dilakukan terhadap proses nasalisasi dalam Bahasa Bidayu-Somu didapati, alomorf $/ \mathrm{Ne}-/$ ini dapat diimbuhkan kepada kata akar dwisuku yang dimulai oleh konsonan liquida. Contohcontoh, diantaranya:

a. Alomorf / $\mathrm{Ne}-/$ sebagai penetap golongan:

1. /labi/ = beritahu / elabi/ = memberitahukan

2. $/$ ronap/ = rendam / Eronap $/=$ merendam

3. $/$ ranap $/=$ pekik / Eranap $/=$ memekik

b. Alomorf $/ \mathrm{Ne}-/$ sebagai pengubah golongan:

4. $/ \mathrm{raNko} /=$ kayu / \&eraNko/ = mengolah $($ jadi papan)

5. $/$ rentes/ = rintisan / erentes $/=$ merintis

6. $/$ lansa?/ = parang, mandau / eelansa?/ = memotong (menggunakan parang, mandau)

7. /lobut/ = popok bayi / elobut $/ \quad=$ menyelimuti (bayi) 
Berdasarkan contoh-contoh di atas memperlihatkan bahwa alomorf / $\mathrm{Ne}-/$ dalam Bahasa Bidayuh-Somu hadir bersama kata akar dwisuku dari golongan kata benda dan kata sifat. Seterusnya berdasarkan penelitian yang dilakukan terhadap nasalisasi dengan alomorf /Ne-/ ini menunjukkan bahwa alomorf $/ \mathrm{Ne}-/$ ini berfungsi menerbitkan kata kerja transitif dengan ciri atau makna 'melakukan sesuatu'. Perhatikan contoh kalimat berikut:

lonu at yoh jeh bua?boyok, go? kay Nelobut ayo $N^{3}$ yoh/

(hari itu tersebut sudah kencang, jangan tidak menyelimuti anak perempuan kecil itu)

/hari itu mulai berangin kencang, jangan lupa menyelimuti anak perempuan kecil itu/

\section{Alomorf penambah /Ni-/}

Kajian yang dilakukan terhadap kata Bahasa Bidayuh-Somu memperlihatkan, alomorf /Ni-/ merupakan pengubah golongan kata. Alomorf ini biasanya hanya dapat ditambahkan kepada kata akar golongan kata nama. Dari contoh-contoh yang diperoleh, alomorf / $\mathrm{Ni}-/$ ini bisa ditambahkan kepada kata akar ekasuku yang dimulai oleh fonem afrikat /c/, lateral /1/, dan getaran $/ \mathrm{r} /$. Berdasarkan pengamatan, alomorf $/ \mathrm{Ni}-/$ ini lebih sering terjadi pada kata akar yang dimulai oleh fonem afrikat tak bersuara $/ \mathrm{c} /$. Berikut ini adalah diantara contoh-contoh penggunaan alomorf / $\mathrm{Ni}-/$ dalam kata Bahasa Bidayuh-Somu:
1. $/$ cap/ = cap
/ icap/ = mengecap
2. /cas/ = isi (tenaga)
/ icas/ = mengisi (tenaga)
3. $/$ cat $/=$ cat
/ icat $/=$ mengecat; mewarnai
4. /lap/ = lap (lantai)

\footnotetext{
${ }^{3}$ Sebutan/panggilan untuk anak kecil yang perempuan. Abang adalah sebutan/panggilan untuk anak kecil lakilaki.
}

$$
\text { / } \text { ilap/ = mengelap (lantai) }
$$

5. /las/ = sambungan pada

besi

/ ilas/ = menyambung besi (dengan dibakar)

6. $/$ lem/ = lem

/ ilem/ = mengelem

7. $/ \mathrm{rem} /=$ rem

/ irem/ = mengerem

Berdasarkan proses pengimbuhan dalam Bahasa Bidayuh-Somu, didapati alomorf $/ \mathrm{Ni}-/$ ini hanya berfungsi sebagai pengubah golongan kata (perhatikan contoh 17 di atas). Berdasarkan fungsi atau kehadiran objek dalam kalimat, didapati alomorf / $\mathrm{Ni}-/$ dalam bahasa ini berfungsi menghasilkan kata kerja transitif dan menunjukkan makna 'melakukan sesuatu'. Lihat contoh kalimat berikut:

lopi PLN taput pojap, moru moka-malak kurija Nilas pigo bosi/

(api PLN lantas padam, akhir terbengkalai pekerjaan mengelas pagar besi)

/gara-gara listrik mati, akhirnya terbengkalai

kegiatan mengelas pagar besi/

Berdasarkan analisis terhadap contohcontoh proses nasalisasi yang berfungsi dalam Bahasa Bidayuh-Somu menunjukkan bahwa proses ini dapat memberikan makna tersendiri, seperti makna-makna: Melakukan sesuatu, Saling melakukan perbuatan (Resiprokal), Mampu, Menuju dan Memiliki.

\section{KESIMPULAN}

Analisis yang dilakukan terhadap contoh-contoh memperlihatkan, proses nasalisasi dalam Bahasa Bidayuh-Somu berfungsi sebagai pengganti dan penambah. Berdasarkan fungsi pengimbuhan didapati, proses nasalisasi tersebut merupakan penetap dan pengubah golongan kata. Sebagai penetap golongan kata, nasalisasi dalam Bahasa 
Bidayuh-Somu boleh diimbuhkan kepada kata akar dari golongan kata kerja. Sedangkan sebagai pengubah golongan kata, nasalisasi dalam Bahasa Bidayuh-Somu dapat diimbuhkan kepada kata akar dari golongan kata benda dan kata sifat. Seterusnya pula berdasarkan kehadiran obyek dalam kalimat menunjukkan, nasalisasi dalam Bahasa Bidayuh-Somu secara umum menerbitkan kata kerja transitif dan menunjukkan maknamakna terterntu.

Walaupun pada umumnya proses nasalisasi terjadi pada kata akar (berkaitan dengan kasus ini, silahkan merujuk Asmah Haji Omar, 1991:32), tetapi hasil analisis data menunjukkan bahwa di dalam Bahasa Bidayuh-Somu terdapat dua kata akar yang mengalami proses nasalisasi dengan penambah nasal $/ \mathrm{m}-/$ pada tingkat morfem. Proses nasalisasi dari kedua contoh tersebut adalah seperti berikut:
1. /uri?/= obat
/puri?/ = mengobati
/mpuri?/ = mengobati
2. /ule?/ = usap (di dahi)
/pule?/ = mengusap (di dahi)
/mpule?/ = mengusap (di dahi)

Proses nasalisasi kedua kata akar tersebut adalah seperti berikut:

1. $\{$ puN- $\}+$ /uri?/ $\rightarrow$ /puri?/, vokal rangkap /u/gugur.

$/ \mathrm{m} /+$ /puri?/ $\rightarrow$ /mpuri?/

2. $\{$ puN- + /ule?/ $\rightarrow$ /pule?/, vokal rangkap /u/gugur.

$/ \mathrm{m} /+$ /pule?/ $\rightarrow$ /mpule?/

Kedua contoh di atas memperlihatkan bahwa proses nasalisasi tersebut terjadi pada tingkat morfem, yaitu morfem $\{\mathrm{puN}-\}$ atau alomorf /pu-/ dengan peluluhan fonem vokal /u/ pada alomorf /pu-/ menjadi alomorf /p/.

\section{DAFTAR PUSTAKA}

Abdullah Hassan. 2007. Linguistik Am. Kuala Lumpur: PTS Profesional.

Asmah Haji Omar. 2008. Kaedah Penyelidikan Bahasa di Lapangan. Kuala Lumpur: Dewan Bahasa dan Pustaka.

Asmah Haji Omar. 2009. Nahu Melayu Mutakhir (edisi kelima). Kuala Lumpur: Dewan Bahasa dan Pustaka.

Asmah Haji Omar. 2013. The Iban Language of Sarawak: A Grammatical Description. Kuala Lumpur: Dewan Bahasa dan Pustaka.

Berry, Margaret. 1975. An Introduction to Systemic Linguistics. London: BT. Batsford.

Bloomfield, Leonard. 1994. Language. Delhi: Motilal Banarsidass.

Crystal, David. 1980. Linguistics. Harmondsworth, Middlesex, England: Penguin Books

de Saussure, Ferdinand. 1986. Course in General Linguistic. Translated and annotated by Roy Harris. La Salle III: Open Court.

Denham, Kristin dan Lobeck, Anne. 2010. Linguistics for Everyone: an Introduction. Boston: Wadsworth Cengage Learning.

Harimurti Kridalaksana. 1996. Pembentukan Kata Dalam Bahasa Indonesia (edisi kedua). Jakarta: Gramedia Pustaka Utama.

Kieffer, Michael J, dan Lesaux, Nonie K. 'Breaking down words to build meaning: Morphology, vocabulary, and reading comprehension in the urban classroom' dalam The reading teacher 61 , no. 2 (2007): 134-144.

Ramlan. 1990. Morfologi: Suatu Tinjauan Deskriptif. Yogyakarta: UP. Karyono.

Rohani Mohd Yusof. 1999. Perbandingan Morfologi Bahasa Melayu dan Bahasa Iban. Tesis Untuk Memenuhi Keperluan Ijazah Doktor Falsafah Jabatan Pengajian 
Melayu Fakulti Sastera dan Sains Sosial Universiti Malaya Kuala Lumpur.

Samsuri. 1980. Analisa Bahasa: Memahami Bahasa Secara Ilmiah (cetakan kedua). Jakarta: Erlangga.

Sudaryanto. 1990. Aneka Konsep Kedataan Lingual Dalam Linguistik. Yogyakarta: Duta Wacana University Press.
Sujarni Alloy, dkk. 2008. Mozaik Dayak: Keberagaman Subsuku dan Bahasa Dayak di Kalimantan Barat. Jon Bamba (editor). Pontianak: Institut Dayakologi. 